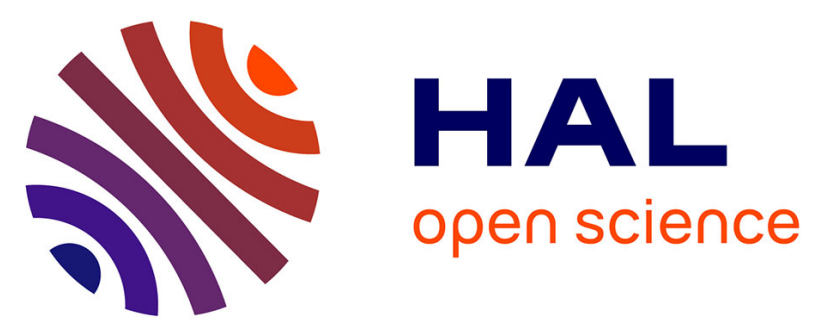

\title{
New acylated flavonol glycosides from the aerial parts of Gouania longipetala
}

\author{
Diane Patricia Apie Gossan, Abdulmagid Alabdul Magid, Philomène Akoua \\ Yao-Kouassi, Antoine Ahibo Coffy, Dominique Harakat, Laurence \\ Voutquenne-Nazabadioko
}

\section{To cite this version:}

Diane Patricia Apie Gossan, Abdulmagid Alabdul Magid, Philomène Akoua Yao-Kouassi, Antoine Ahibo Coffy, Dominique Harakat, et al.. New acylated flavonol glycosides from the aerial parts of Gouania longipetala. Phytochemistry Letters, 2015, 11, pp.306-310. 10.1016/j.phytol.2015.01.019 . hal-01996573

\section{HAL Id: hal-01996573 \\ https://hal.univ-reims.fr/hal-01996573}

Submitted on 28 Oct 2021

HAL is a multi-disciplinary open access archive for the deposit and dissemination of scientific research documents, whether they are published or not. The documents may come from teaching and research institutions in France or abroad, or from public or private research centers.
L'archive ouverte pluridisciplinaire HAL, est destinée au dépôt et à la diffusion de documents scientifiques de niveau recherche, publiés ou non, émanant des établissements d'enseignement et de recherche français ou étrangers, des laboratoires publics ou privés. 


\section{New acylated flavonol glycosides from the aerial parts of Gouania longipetala}

Diane Patricia Apie Gossan ${ }^{\mathrm{a}, \mathrm{b}}$, Abdulmagid Alabdul Magid ${ }^{*}$, Philomène Akoua Yao-Kouassi ${ }^{\mathrm{b}}$, Antoine Ahibo Coffy ${ }^{\mathrm{b}}$, Dominique Harakat ${ }^{\mathrm{c}}$, Laurence Voutquenne-Nazabadioko ${ }^{\mathrm{a}}$

aCMR-UMR CNRS 7312, Groupe Isolement et Structure, Campus Sciences, Bat. 18, BP 1039, 51687 Reims Cedex 2, France

bLaboratoire de Chimie Organique Biologique, 01 BPV 34 Abidjan 01, Université Félix-Houphouët Boigny d'Abidjan-Cocody, Côte d'Ivoire

'ICMR-UMR CNRS 7312, Service Commun d'Analyses, Campus Sciences, Bat. 18, BP 1039, 51687 Reims Cedex 2, France

* Corresponding author. Tel.: +33-3-26-91-82-08; fax: +33-3-26-91-35-96. E-mail address: abdulmagid.alabdulmagid@univ-reims.fr (A. Alabdul Magid) 


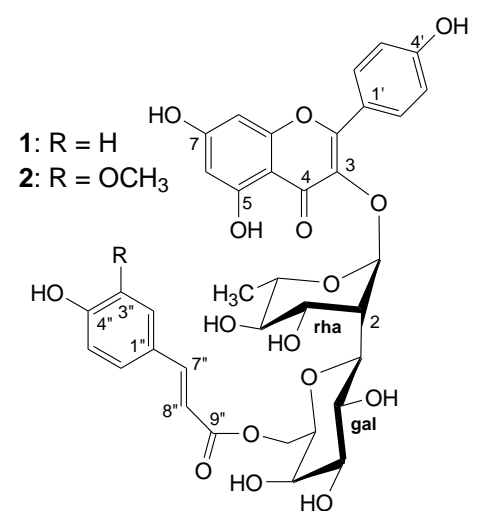

\title{
Highlights
}

Two new acylated flavonol glycosides were isolated from Gouania longipetala.

Their structures were established on the basis of NMR spectroscopy and HRESIMS.

Four flavonoids isolated from this plant showed significant antioxidant effects.

\begin{abstract}
Two new flavonol diglycosides kaempferol-3-O-(6-O-trans- $p$-coumaroyl)- $\beta$-D-galactopyranosyl$(1 \rightarrow 2)$ - $\alpha$-L-rhamnopyranoside and kaempferol-3-O-[6-O-trans-feruloyl)- $\beta$-D-galactopyranosyl$(1 \rightarrow 2)$ - $\alpha$-L rhamnopyranoside were isolated from the aerial parts of Gouania longipetala in addition to seven known compounds. The structure elucidation of these compounds was based on analyses of spectroscopic data including 1D- and 2D-NMR and HR-ESI-MS techniques. The abilities of these compounds to scavenge the DPPH were evaluated. . Results showed that compounds $2, \mathbf{3 , 8}$ and 9 have significant antioxidant potential with $\mathrm{EC}_{50}$ values ranging from 13.8 to $47.4 \mu \mathrm{M}$, compared with ascorbic acid $\left(\mathrm{EC}_{50} 60 \mu \mathrm{M}\right)$ which was used as positive control.
\end{abstract}

Keywords: Gouania longipetala; Rhamnaceae; Flavonoids; DPPH free radical scavenging activity. 


\section{Introduction}

Gouania is a plant genus comprising 70 tropical and subtropical species belonging to the family Rhamnaceae (Yao et al., 2011). Previous chemical investigation of this genus has demonstrated the presence of triterpenes and polyphenols (Giacomelli et al., 2007, Kennely et al., 1993, Li et al., 2007, Nair and Rao, 1993, Yao et al., 2011). Gouania longipetala (Hemsl.) is a scandent shrub or liana mainly present in closed forests, forest margins and in jungle regrowths. It occurs in Angola, Cameroun, Congo, Guinea, and Southwest of Ivory Coast (Burkill et al., 1985). Its salient characteristics are the watch spring tendrils, spike-like thyrsus, a more or less lobed disc, inferior ovary and longitudinally three-winged septicidal fruits (Buerki et al., 2011). G. longipetala has been used in traditional medicine for the treatment of different ailments such as edema, venomous stings, gout, abdominal pain and stomach troubles (Ezeja et al., 2014). It is also used for eye treatments, pain killers and for treating heart disease. The stem extract of the plant has been shown to possess antibacterial, anti-inflammatory, and antioxidant activities (Ekuadzi et al., 2012). This present study deals with the isolation and structure elucidation of nine flavonol glycosides from the methanol extract of the aerial parts including two new acylated flavonol diglycosides and seven known compounds. The methanol extract and isolated compounds were evaluated for their antioxidant activity by using a DPPH radical-scavenging assay.

\section{Results and discussion}

The methanolic extract of the aerial parts of $G$. longipetala was separated by combination of chromatographic methods to obtain two new flavonol glycosides $\mathbf{1}$ and 2 (Fig. 1) in addition to seven known compounds. The sugar composition was determined by comparative TLC after acid hydrolysis of the flavonoid mixture as xylose (xyl), glucose (glc), galactose (gal) and rhamnose (rha) and their common D-xyl, D-glc, D-gal, or L-rha configurations were verified by measurement of the optical rotation of each purified sugar. The known compounds were elucidated as kaempferol-3-O- $\alpha$-L-rhamnopyranosyl-( $1 \rightarrow 6)-\beta$-D-galactopyranoside (3) (Brasseur and Agenot, 1986), kaempferol-3-O- $\alpha$-L-rhamnopyranosyl-(1 $\rightarrow 6)-\beta$-D -glucopyranoside (4) (Pawlowska et al., 2009), kaempferol-3-O- $\alpha$-L-rhamnopyranoside (5) (Mok and Lee, 2013), kaempferol-3-O- $\beta$-Dxylopyranosyl-(1 $\rightarrow 2)-\alpha$-L-rhamnopyranoside (6) (Soicke et al., 1990), kaempferol-3-O- $\beta$-Dgalactopyranosyl-(1 $\rightarrow 2)$ - $\alpha$-L-rhamnopyranoside (7) (Szewczyk et al., 2014), quercetin-3-O- $\beta$-D-

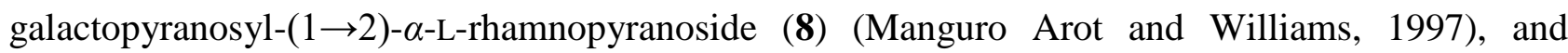

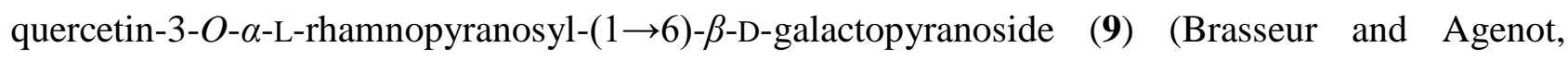
1986). Their structural assignments were made by HR-ESI-MS, 1D, and 2D NMR analysis. Their spectroscopic data were in good agreement with those reported in the literature. 
Compound 1, $[\alpha]_{\mathrm{D}}{ }^{20}-19.7$, was isolated as a yellow amorphous powder. The positive HR-ESI-MS showed a molecular ion peak at $\mathrm{m} / z$. $763.1856[\mathrm{M}+\mathrm{Na}]^{+}$, (calcd for $\mathrm{C}_{36} \mathrm{H}_{36} \mathrm{O}_{17} \mathrm{Na}, 763.1850$ ) enabling us to determine the molecular formula $\mathrm{C}_{36} \mathrm{H}_{36} \mathrm{O}_{17}$. The $\mathrm{UV}$ spectrum displayed maximum absorption bands of a flavonol skeleton at $\lambda_{\max } 267$ and $314 \mathrm{~nm}$. The ${ }^{1} \mathrm{H}$ and ${ }^{13} \mathrm{C}$ NMR spectra of 1 comprised resonances corresponding to aromatic and glycosidic protons and carbons. The A-ring of the flavonol was represented by two meta-coupled resonances at $\delta_{\mathrm{H}} 6.17\left(\mathrm{~d}, J=2.2 \mathrm{~Hz}, \delta_{\mathrm{C}} 99.8\right)$ and $\delta_{\mathrm{H}} 6.18\left(\mathrm{~d}, J=2.2 \mathrm{~Hz}, \delta_{\mathrm{C}} 94.9\right)$, assigned to $\mathrm{H}-6$ and $\mathrm{H}-8$, respectively. The ${ }^{1} \mathrm{H}$ and COSY NMR spectra of 1 (Table 1) exhibited two ortho-coupled doublet signals at $\delta_{\mathrm{H}} 7.70$ and 6.93 (each $2 \mathrm{H}, \mathrm{d}$, $J=8.4 \mathrm{~Hz}$ ) revealing the presence of an $\mathrm{AA}^{\prime} \mathrm{BB}^{\prime}$ system of ring $\mathrm{B}$ of the aglycone assignable to $\mathrm{H}$ $2^{\prime} / 6^{\prime}$ and $\mathrm{H}-3^{\prime} / 5^{\prime}$ respectively, which were correlated in the HSQC spectrum with their aromatic carbon atoms at 131.9 and 116.4 ppm, respectively. Complete assignment of the remaining resonances of the aglycone in the ${ }^{13} \mathrm{C}$ NMR spectrum of $\mathbf{1}$ was achieved by analysis of the HSQC and HMBC data, which confirmed the presence of kaempferol (3,5,7,4'-tetrahydroxy-flavone). A full list of the corresponding assignments is given in Table 1 (Sahakitpichan et al., 2014, Tang et al., 2001). The COSY and ${ }^{1} \mathrm{H}$ NMR spectra of 1 also showed four aromatic protons at $\delta_{\mathrm{H}} 7.23$ and 6.70 (each $2 \mathrm{H}, \mathrm{d}, J=8.3 \mathrm{~Hz}$ ) assignable to $\mathrm{H}-2^{\prime \prime} / 6^{\prime \prime}$ and $\mathrm{H}-3^{\prime \prime} / 5^{\prime \prime}$ respectively and two olefinic protons at $\delta_{\mathrm{H}} 7.47$ and 6.04 (each $1 \mathrm{H}, \mathrm{d}, J=16.0 \mathrm{~Hz}$ ) assignable to $\mathrm{H}-7{ }^{\prime \prime}$ and $\mathrm{H}-8^{\prime \prime}$. These data were consistent with the presence of an E-coumaroyl moiety (Table 1) (Bendaikha et al., 2014) and its ${ }^{1} \mathrm{H}$ and ${ }^{13} \mathrm{C}$ resonances were assigned using 2D NMR experiments (COSY, HSQC, and HMBC). Furthermore, two anomeric proton resonances corresponding to $O$-linked sugars were displayed in the ${ }^{1} \mathrm{H}$ NMR spectrum as two doublets at $\delta_{\mathrm{H}} 4.44(J=7.7 \mathrm{~Hz})$ and $5.85(J=1.2 \mathrm{~Hz})$. Based on the results of the acid hydrolysis of flavonoids mixture, the magnitudes of their $J_{1,2}$ coupling constants and the analysis of $1 \mathrm{D}$ and $2 \mathrm{D}$ NMR data, the sugar units were elucidated as $\beta$-D-galactopyranose $\left(\delta_{\mathrm{H}-1} 4.44\right.$ and $\left.\delta_{\mathrm{C}-1} 107.6\right)$ and $\alpha$-L-rhamnopyranose $\left(\delta_{\mathrm{H}-1} 5.85\right.$ and $\left.\delta_{\mathrm{C}-1} 102.3\right)$ (Table 1) (Agrawal, 1992). The $\beta$-D-gal was characterized by the large coupling constants $J_{\mathrm{H}-1, \mathrm{H}-2}$ and $J_{\mathrm{H}-2, \mathrm{H}-3}(>7.7 \mathrm{~Hz})$ and the small coupling constant $J_{\mathrm{H}-3, \mathrm{H}-4}(3.3 \mathrm{~Hz})$ whereas the $\alpha$-L-rha was characterized by the small coupling constants $J_{\mathrm{H}-1, \mathrm{H}-2}(1.2 \mathrm{~Hz})$ and its methyl group at $\delta_{\mathrm{H}-6} 1.07(\mathrm{~d}, J=6.2 \mathrm{~Hz})$ and $\delta_{\mathrm{C}-6} 17.8$ as summarized in Table 1. A correlation between H-1-rha and $\delta_{\mathrm{C}} 136.7$ in the HMBC spectrum of 1 defined C-3 of kaempferol as the site of $O$-glycosylation. The interglycosidic linkage of the disaccharide moiety was also determined from HMBC data. Correlations from $\mathrm{H}-1$-gal to the downfield-shifted C-2-rha $\left(\delta_{\mathrm{C}} 83.6\right)$ indicated that the gal residue was 2-O-linked to rha. Furthermore, the downfield shifted methylene protons H-6-gal ( $\delta_{\mathrm{H}} 4.24$ and 4.40$)$ and the HMBC correlation observed between these protons and the ester carbonyl at $\delta$ c 168.8 indicated the 
attachment of the E-coumaroyl group to C-6-gal. Therefore, the structure of compound 1 was determined as kaempferol-3- $O$-(6- $O-E$ - $p$-coumaroyl)- $\beta$-D-galactopyranosyl-( $1 \rightarrow 2)-\alpha$-Lrhamnopyranoside.

Compound 2, $[\alpha]_{\mathrm{D}}{ }^{20}-23.2$, was obtained as a yellow amorphous powder and displayed a molecular ion peak $[\mathrm{M}+\mathrm{Na}]^{+}$at $m / z, 793.1966$ in the positive HR-ESI-MS, (calcd for $\mathrm{C}_{37} \mathrm{H}_{38} \mathrm{O}_{18} \mathrm{Na}, 793.1956$ ) in agreement with a molecular formula of $\mathrm{C}_{37} \mathrm{H}_{38} \mathrm{O}_{18} \mathrm{~N}$ and indicating an additional methoxy group by comparison with 1 . It exhibited an absorption band at $\lambda_{\max } 266$ and $326 \mathrm{~nm}$ suggesting a flavonol skeleton. Analysis of 2D NMR experiments of 2 and comparison of its ${ }^{1} \mathrm{H}$ and ${ }^{13} \mathrm{C}$ NMR data with those of $\mathbf{1}$ showed that $\mathbf{2}$ was kaempferol glycoside acylated with cinnamic acid derivative and contained the same disaccharide chain linked to C-3 of kaempferol (Table 1). This disaccharide was elucidated as above as $\beta$-D-galactopyranosyl-( $1 \rightarrow 2)$ - $\alpha$-L-rhamnopyranoside. Thus the additional methoxy group $\left[\delta_{\mathrm{H}} 3.78(3 \mathrm{H}, \mathrm{s}) ; \delta_{\mathrm{C}} 56.2\right]$ should be located at the cinnamoyl derivative. This latter was represented on the ${ }^{1} \mathrm{H}$ NMR spectrum by two trans-coupled double-bond protons at $\delta_{\mathrm{H}} 7.44(\mathrm{H}$ $\left.7^{\prime \prime}\right)$ and $6.06\left(\mathrm{H}-8^{\prime \prime}\right)($ each $\mathrm{H}, \mathrm{d}, J=15.9 \mathrm{~Hz})$, and three coupled aromatic protons $\delta_{\mathrm{H}} 6.88(\mathrm{~d}, J=1.6$ $\left.\mathrm{Hz}, \mathrm{H}-2^{\prime \prime}\right), 6.69$ (d, $\left.J=8.2 \mathrm{~Hz}, \mathrm{H}-5^{\prime \prime}\right)$, and 6.83 (dd, $\left.J=8.2,1.6 \mathrm{~Hz}, \mathrm{H}-6^{\prime \prime}\right)$. The presence of an $E-$ feruloyl moiety was evident by the connectivities observed in the HMBC spectrum between the trans double-bond and the 1,3,4-substituted aromatic ring as well as to an ester carbonyl ( $\delta \mathrm{C} 168.7)$, and from the protons of the methoxy group to the C-3" ( $\left.\delta_{\mathrm{C}} 149.1\right)$ of the feruloyl moiety (Bendaikha et al., 2014). Full assignments of the proton and carbon resonances of $\mathbf{2}$ were achieved by analysis of the COSY, HSQC and HMBC spectra (Table 1). The site of glycosylation was established at the 3-OH position of kaempferol, as demonstrated by the HMBC spectrum showing correlations from H-1-rha to C-3 kaempferol and from H-1-gal to C-2-rha. The $E$-feruloyl was linked to OH-6-gal as indicated by the downfield shifts of H-6-gal ( $\delta_{\mathrm{H}} 4.23$ and 4.47) and was confirmed by the cross peak between H-6-gal and the carbonyl C-9" in the HMBC experiment. The structure of 2 was therefore identified as $\quad$ kaempferol-3- $O$-(6- $O$ - $E$-feruloyl)- $\beta$-D-galactopyranosyl-( $1 \rightarrow 2)-\alpha$-Lrhamnopyranoside.

In order to assess the antioxidative properties of 1-9, the DPPH radical scavenging activity of these compounds was measured. According to the results, summarized in Table 2, compounds $\mathbf{2 , 3}, \mathbf{8}$, and 9 had significant antioxidant potential ( $\mathrm{EC}_{50}$ values ranging from 13.8 to $47.4 \mu \mathrm{M}$ ) compared with ascorbic acid, which was used as a positive control $\left(\mathrm{EC}_{50} 60 \mu \mathrm{M}\right)$. Generally, substitution patterns on the B-ring especially affected antioxidant potencies of the flavonoids (Arora et al., 1998). The di-OH substitution at $3^{\prime}$ and $4^{\prime}$ of the B-ring is particularly important to the antiradical activity of a flavonoid. These trends are consistent with less active flavonoids $(\mathbf{1}, \mathbf{4}, \mathbf{6}$, and $\mathbf{7})$ that possess mono$\mathrm{OH}$ substitution in the B-ring. Compounds 1-4, 6, and 7 shared a common aglycone mono-OH 
substituted in the B-ring (kaempferol). Comparison of the antioxidant activity of $\mathbf{1}$ and $\mathbf{2}$ indicated that acylation with feruloyl moiety (2) was more favorable for the antioxidant activity than acylation with coumaroyl (1) residue.

Comparison of the antioxidant activity of kaempferol diglycosides $\mathbf{3}, \mathbf{4}, \mathbf{6}$, and $\mathbf{7}$ indicated that compounds 3 and 7 (EC50 40.4 and $90.4 \mu \mathrm{M}$, respectively) with a disaccharide chain composed of rhamnose-galactose were more active than compounds $\mathbf{4}$ and $\mathbf{6}$ whose disaccharide chains were composed of rhamnose-glucose or rhamnose-xylose. These results indicated that galactose residue in 3 and 7 was more favorable for the activity than glucose (4) or xylose (6). Comparison of the antioxidant activity of $\mathbf{8}$ and $\mathbf{9}$ (EC $\mathrm{EC}_{50} 13.8$ and $41.5 \mu \mathrm{M}$, respectively) showed that $\mathbf{8}$ possessing the saccharide chain gal-( $1 \rightarrow 2)$-rha- was 3 times more active than 9 possessing the saccharide chain rha- $(1 \rightarrow 6)$-gal-. These finding suggested that the saccharide chain linked at C-3 of the aglycone might contribute to the antioxidant activity.

\section{Experimental}

\subsection{General experimental procedures}

NMR spectra were carried in $\mathrm{MeOH}-d_{4}$ on Bruker Avance DRX III 500 instruments $\left({ }^{1} \mathrm{H}\right.$ at 500 $\mathrm{MHz}$ and ${ }^{13} \mathrm{C}$ at $\left.125 \mathrm{MHz}\right)$. Standard pulse sequences and parameters were used to obtain $1 \mathrm{D}\left({ }^{1} \mathrm{H}\right.$ and ${ }^{13} \mathrm{C}$ ) and 2D (COSY, HSQC, and HMBC) spectra. Chemical shift referencing was carried out using the internal solvent resonances at $\delta_{\mathrm{H}} 3.31$ and $\delta_{\mathrm{C}}$ 49.0. HR-ESI-MS experiments were performed using a Micromass Q-TOF micro instrument (Manchester, UK). Optical rotations were determined in $\mathrm{MeOH}$ with a Perkin-Elmer 341 polarimeter. TLC was performed on pre-coated silica-gel $60 \mathrm{~F}_{254}$ Merck and compounds were observed under UV light at 254 and $365 \mathrm{~nm}$ or visualized by spraying the dried plates with $50 \% \mathrm{H}_{2} \mathrm{SO}_{4}$, followed by heating. $\mathrm{CC}$ was carried out on Kieselgel 60 (63-200 mesh), or LiChroprep RP-18 (40-63 $\mu \mathrm{m}$ ) Merck. HPLC was performed on a Dionex apparatus equipped with an ASI-100 autosampler, an Ultimate 3000 pump, a diode array detector UVD 340S and Chromeleon software. C18 reversed phase column (Phenomenex 250x10 $\mathrm{mm}$, Luna $5 \mu)$ was used for semi preparative HPLC with binary gradient eluent $\left(\mathrm{H}_{2} \mathrm{O}(\mathrm{pH} 2.4\right.$ with TFA); $\mathrm{MeOH}$ ) and a flow rate of $3 \mathrm{ml} / \mathrm{min}$; the chromatogram was monitored at 205, 225, 250, and $350 \mathrm{~nm}$. Absorbance (A) values in the DPPH free radical scavenging assay were read on a Fluostar omega microplate reader (BMG labtech). UV spectra were recorded on Shimadzu UV-2450 spectrophotometer in $\mathrm{MeOH}$.

\subsection{Plant material}

The aerial parts of $G$. longipetala were collected in Gagnoa-Bayota, Abidjan, Ivory Coast, in September 2009. A voucher specimen (No Aké Assi S.N-02) has been deposited in the herbarium of the National Center of Floristic of FHB University of Cocody (Ivory Coast). 


\subsection{Extraction and isolation}

The powdered dry aerial parts of G. longipetala $(950 \mathrm{~g}$ ) were sequentially extracted with 191 of petroleum ether, ethyl acetate and methanol at room temperature for $24 \mathrm{~h}$. After evaporation of the solvents, $7.9 \mathrm{~g}$ of petroleum ether extract, $4.7 \mathrm{~g}$ of ethyl acetate extract and $26.5 \mathrm{~g}$ of methanol extract were obtained. The methanol extract was subjected to VLC over RP-18 (9 x $5 \mathrm{~cm})$ eluted successively with $20,40,60,80$, and $100 \% \mathrm{MeOH}$ in $\mathrm{H}_{2} \mathrm{O}$, to give five fractions $\left(\mathrm{A}_{1}-\mathrm{A}_{5}\right.$, respectively). Fraction $\mathrm{A}_{2}(2.3 \mathrm{~g})$ was applied to a RP-18 CC (2 x $\left.16 \mathrm{~cm}\right)$ eluted with a gradient of $\mathrm{MeOH}: \mathrm{H}_{2} \mathrm{O}$ (2:8-5:5) to afford 130 fractions, each $30 \mathrm{ml}$. Frs [48-50] (96 mg), eluted with $\mathrm{MeOH}: \mathrm{H}_{2} \mathrm{O}$ (35:65), were purified by silica gel CC eluted with a gradient of $\mathrm{CHCl}_{3}: \mathrm{MeOH}(9: 1-$ 7:3) yielding compound 9 (12 mg). Frs [55-80] (367 mg), eluted with $\mathrm{MeOH}: \mathrm{H}_{2} \mathrm{O}$ (35:65), were purified by silica gel CC eluted with a gradient of $\mathrm{CHCl}_{3}: \mathrm{MeOH}(9: 1-6: 4)$ to yield compounds 3 $(14 \mathrm{mg})$ and $8(14 \mathrm{mg})$. Fraction $\mathrm{A}_{3}(5.5 \mathrm{~g})$ was applied to a silica gel VLC $(9 \times 5 \mathrm{~cm})$ eluted with $\mathrm{CHCl}_{3}: \mathrm{MeOH}: \mathrm{H}_{2} \mathrm{O}(9: 1: 0-60: 40: 7)$ to give six fractions $\left(\mathrm{B}_{1}-\mathrm{B}_{6}\right.$, respectively), each $280 \mathrm{ml}$. Fraction $\mathrm{B}_{5}(1.8 \mathrm{~g})$, eluted with $\mathrm{CHCl}_{3}: \mathrm{MeOH}: \mathrm{H}_{2} \mathrm{O}(14: 6: 1)$ was further purified over silica gel CC (2.8 x 24 cm, 40 fractions, each $100 \mathrm{ml}$ ). Frs [5-9] (83 mg), eluted with $\mathrm{CHCl}_{3}: \mathrm{MeOH}(9: 1)$ were purified by semi-prep HPLC using 50\% of MeOH for 30 min yielding compound 5 ( $r t 17.5$ min, 16 mg). Frs [13-17] (331 mg), eluted with $\mathrm{CHCl}_{3}: \mathrm{MeOH}$ (85:15) were applied to a silica gel CC eluted with a gradient of $\mathrm{CHCl}_{3}: \mathrm{MeOH}$ (9:1-7:3) to afford $64 \mathrm{mg}$ of compound 7 (eluted with 85:15 of $\left.\mathrm{CHCl}_{3}: \mathrm{MeOH}\right)$ and fraction eluted with $\mathrm{CHCl}_{3}: \mathrm{MeOH}(8: 2)$ were further purified by semi-prep HPLC using 50\% of MeOH for 35 min yielding compounds 6 ( $r t 12.5 \mathrm{~min}, 9 \mathrm{mg}$ ), 4 ( $r t 13.5 \mathrm{~min}, 8$ $\mathrm{mg}$ ), 2 (rt $21.1 \mathrm{~min}, 10 \mathrm{mg}$ ), and $\mathbf{1}$ (rt $32.5 \mathrm{~min}, 24 \mathrm{mg}$ ).

\subsection{Acid hydrolysis}

A part of fractions $\mathrm{A}_{2}$ and $\mathrm{A}_{3}\left(500 \mathrm{mg}\right.$ each) was refluxed $\left(90^{\circ} \mathrm{C}\right)$ with $50 \mathrm{ml}$ of $2 \mathrm{M}$ TFA for $4 \mathrm{~h}$. After extraction with ethyl acetate $(3 \times 30 \mathrm{ml})$, the aqueous layer was evaporated to furnish the monosaccharide residue $(300 \mathrm{mg})$. Four sugars were identified as xylose, glucose, galactose and rhamnose by comparison with authentic samples on TLC in MeCOEt:iso-PrOH:acetone: $\mathrm{H}_{2} \mathrm{O}$ (20:10:7:6). A part of the monosaccharide residue (50 $\mathrm{mg}$ ) was subjected to a preparative TLC using the same solvent. The optical rotation of each purified sugar was measured to reveal rhamnose $\left([\alpha]^{20}{ }_{D}+2.4,\left(c 1, \mathrm{H}_{2} \mathrm{O}\right)\right)$, glucose $\left([\alpha]^{20}{ }_{\mathrm{D}}+27.6,\left(c 0.75, \mathrm{H}_{2} \mathrm{O}\right)\right)$, xylose $\left([\alpha]^{20}{ }_{\mathrm{D}}+15.1,(c\right.$ $\left.\left.0.95, \mathrm{H}_{2} \mathrm{O}\right)\right)$ and galactose $\left([\alpha]^{20}{ }_{\mathrm{D}}+41.2,\left(c 1, \mathrm{H}_{2} \mathrm{O}\right)\right)$.

3.5. kaempferol-3-O-(6-O-E-p-coumaroyl)- $\beta$-D-galactopyranosyl-(1 $\rightarrow 2)$ - $\alpha$-L-rhamnopyranoside (1) $[\alpha]^{20}{ }_{\mathrm{D}}-19.7$ ( $c$ 0.3, MeOH); UV (MeOH) $\lambda_{\max } \mathrm{nm}(\mathrm{A}): 314$ (1.54), 295 (1.41), 267 (1.23); ${ }^{1} \mathrm{H}$ and

${ }^{13} \mathrm{C}$ NMR $\left(\mathrm{MeOH}-d_{4}\right)$ spectroscopic data, see Table 1; HR-ESI-MS $m / z: 763.1856[\mathrm{M}+\mathrm{Na}]^{+}(\mathrm{calcd}$ for $\mathrm{C}_{36} \mathrm{H}_{36} \mathrm{O}_{17} \mathrm{Na}, 763.1850$ ).

3.6. kaempferol-3-O-(6-O-E-feruloyl)- $\beta$-D-galactopyranosyl- $(1 \rightarrow 2)$ - $\alpha$-L-rhamnopyranoside (2) 
$[\alpha]^{20}{ }_{\mathrm{D}}-23.2\left(c\right.$ 0.25, MeOH); UV (MeOH) $\lambda_{\max } \mathrm{nm}(\mathrm{A}): 326(1.05), 305(0.80), 266(0.85) ;{ }^{1} \mathrm{H}$ and

${ }^{13} \mathrm{C}$ NMR $\left(\mathrm{MeOH}-d_{4}\right)$ spectroscopic data, see Table 1; HR-ESI-MS m/z: $793.1966[\mathrm{M}+\mathrm{Na}]^{+}(\mathrm{calcd}$ for $\mathrm{C}_{37} \mathrm{H}_{38} \mathrm{O}_{18} \mathrm{Na}$, 793.1956).

\subsection{DPPH free radical scavenging assay}

DPPH (1,1-diphenyl-2-picrylhydrazyl radical) and ascorbic acid used for the bioassay were purchased from Sigma-Aldrich, Chemical Co. (Germany). The scavenging activity of isolated compounds against DPPH was investigated by spectrophotometric methodology as described by Lee et al. (1998) with slight modification. Briefly, $5 \mu \mathrm{l}$ of the standard or sample solutions (dissolved in DMSO) was mixed with $95 \mu \mathrm{l}$ of DPPH solution $(158 \mu \mathrm{M}$, dissolved in absolute EtOH). After mixing gently and incubating for $30 \mathrm{~min}$ at $37^{\circ} \mathrm{C}$, the optical density was measured at $\lambda 515 \mathrm{~nm}$ using a Fluostar omega microplate reader (BMG labtech). The percentage of absorbance inhibition at $\lambda 515 \mathrm{~nm}$ was calculated using the following equation: \% inhibition [( $\mathrm{A}_{\text {control }}$ $\left.\left.\mathrm{A}_{\text {sample }}\right) / \mathrm{A}_{\text {control }}\right] \times 100 . \mathrm{DPPH}$ solution in $\mathrm{EtOH}$ was used as a control. The curve of the \% scavenging activity against the concentration of sample was prepared by an MSExcel based program to obtain the $\mathrm{EC}_{50}$ (concentration required to obtain a $50 \%$ antioxidant effect). All the tests were conducted in triplicate. The experimental data were expressed as mean \pm standard deviation.

\section{Acknowledgements.}

The authors are grateful to CNRS, Conseil Régional Champagne Ardenne, Conseil Général de la Marne, and Ministry of Higher Education and Research (MESR), and to the PIANET CPER project for financial support.

\section{References}

Agrawal P.K.1992. NMR Spectroscopy in the structural elucidation of oligosaccharides and glycosides. Phytochemistry 31, 3307-3330.

Arora, A., Nair, M.G., Strasburg, G.M., 1998. Structure-activity relationships for antioxidant activities of a series of flavonoids in a liposomal system.Free Radic Biol Med.24, 1355-63.

Bendaikha, S., Gadaut, M., Harakat, D., Alabdul Magid, A., 2014. Acylated flavonol glycosides from the flower of Elaeagnus angustifolia L. Phytochemistry 103, 129-13.

Buerki, S., Philipson, P.B., Callmander, M.W., 2011. A taxonomic revision of Gouania (Rhamnaceae) in Madagascar and the other Islands of Western Indian ocean. Ann. Mo.Bot.Gard.98, 157-195.

Burkill, H.M., 1985. The Useful Plants of West Tropical Africa. The trustees of the Royal Botanical Garden, Kew, UK.

Brasseur, T., Angenot, L., 1986. Flavonol glycosides from leaves of Strychnos variabilis. Phytochemistry 25, 563-564. 
Ekuadzi, E., Dickson, R.A., Fleischer, T.C., 2012. Antibacterial, anti-inflammatory and antioxidant properties of Gouania longipetala Hemsl. IJPSR. 3, 1300-1305.

Ekuadzi, E., Dickson, R.A., Fleischer, T.C., Amponsah, I.K., Pistorius D. and Oberer L., 2014. Chemical constituents from Gouania longipetala and Glyphaea brevis. Nat. Prod. Res. 28, 1210-1213.

Ezeja, M.I., Anaga, A.O., Asuzu, I. O., 2014. Effect of Gouania longipetala (Hemsl.) methanolic leaf extract on the kidney and hematology of alloxan-induced hyperglycemic Wistar rats. Comp Clin Pathol, 23, 1697-1702.

Giacomelli, S. R., Maldaner, G., Stüker, C. 2007.Triterpenoids from Gouania ulmifolia. Planta Med. 73, 499-501.

Kennelly, E. J., Lewis, W. H. 1993.Triterpenoid Saponins from Gouania lupuloides. J. Nat. Prod. $56,402-410$.

Lee, S.K., Mbwambo, Z.H., Chung, H.S., Luyengi, L., Gamez, E.J.C., Mehta, R.G., Kinghorn, A.D., Pezzuto, J.M., 1998. Evaluation of the antioxidant potential of natural products. Comb. Chem. High Throughput Screen. 1, 35-46.

Li, X, Ohtsuki, T, Shindo, S, Sato, M., Koyano, T. 2007.Mangiferin identified in a screening study guided by neuramindase inhibitory activity. Planta Med. 73, 1195-1196.

Manguro Arot, L.O., Williams, L.A.D., 1997. A flavonol glycoside from Embelia schimperi leaves. Phytochemistry 44, 1397-1398.

Mok, S.-Y., Lee, S., 2013. Identification of flavonoids and flavonoid rhamnosides from Rhododendron mucronulatum for. albiflorum and their inhibitory activities against aldose reductase. Food Chem. 136, 969-974.

Nair, S P., Rao, J. M. 1993. Gouanic acid from the leaves of Gouania microcarpa. Phytochemistry $33,711-712$.

Pawlowska, A.M., Camangi, F., Bader, A., Braca, A., 2009. Flavonoids of Zizyphus jujube L. and Zizyphus spina-christi (L) Wild (Rhamnaceae) fruits. Food Chem. 112, 858-862.

Sahakitpichan, P, Chadmuk, P., Disadee, W., Chimnoi, N., Ruchirawat, S., Kanchanapoom, T., 2014. New trans- and cis-p-coumaroyl flavonol tetraglycosides from the leaves of Mitragyna rotundifolia. Phytochemistry letters 8, 65-68.

Soicke, H., Görler, K., Waring, H., 1990. Flavonol Glycosides from Moghania faginea. Planta Med. 56, 410-412.

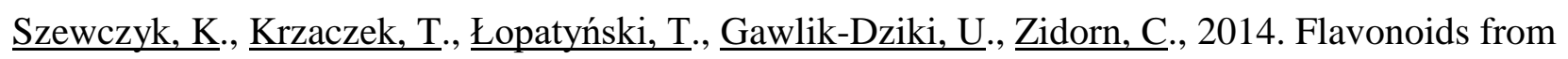
Jovibarba globifera (Crassulaceae) rosette leaves and their antioxidant activity. Nat Prod Res. $28,1655-1658$. 
Tang, Y., Lou, F., Wang, J., Li, Y., Zhuang, S., 2001. Coumaroyl flavonol glycosides from the leaves of Ginkgo biloba. Phytochemistry 58, 1251-1256.

Yao, C., Zhang, S. J., Bai, Z. Z, Zhou, T., Xuan, L. J. 2011. Two new benzopyran derivatives from Gouania leptostachya DC. var. tonkinensis Pitard. Chinese Chem. Lett. 22, 175-177. 

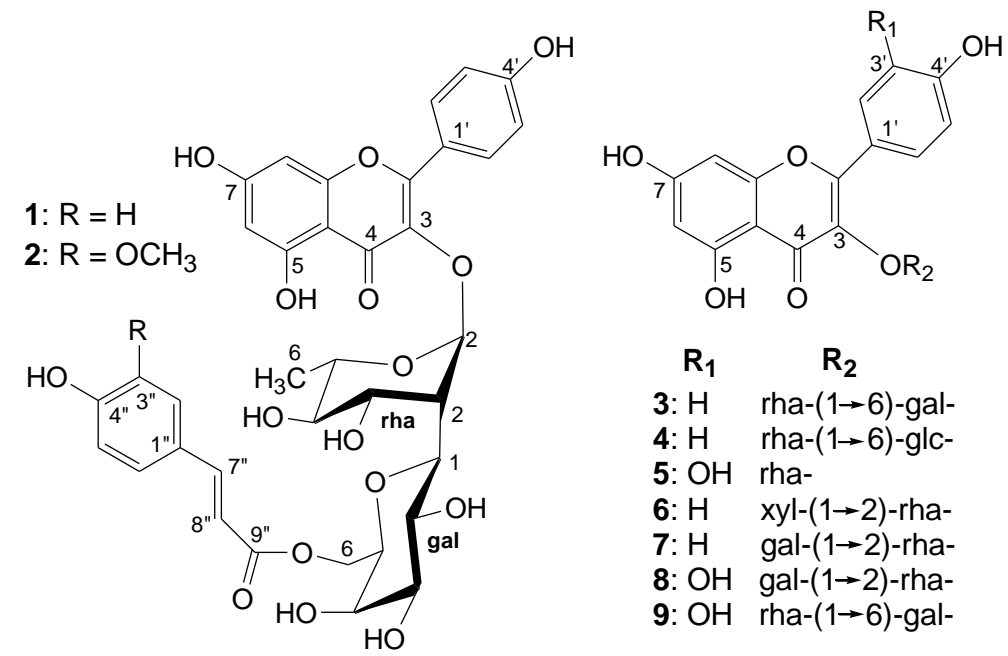

$\mathbf{R}_{\mathbf{1}} \quad \mathbf{R}_{\mathbf{2}}$

3: $\mathrm{H}$ rha- $(1 \rightarrow 6)$-gal-

4: $\mathrm{H}$ rha- $(1 \rightarrow 6)$-glc-

5: $\mathrm{OH}$ rha-

6: $\mathrm{H}$ xyl-(1 $\rightarrow 2)$-rha-

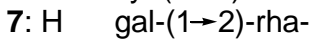

8: $\mathrm{OH}$ gal-( $1 \rightarrow 2)$-rha-

9: $\mathrm{OH}$ rha- $(1 \rightarrow 6)-$ gal-

Fig.1. Chemical structures of flavonoids 1- 9, isolated from G. longipetala.

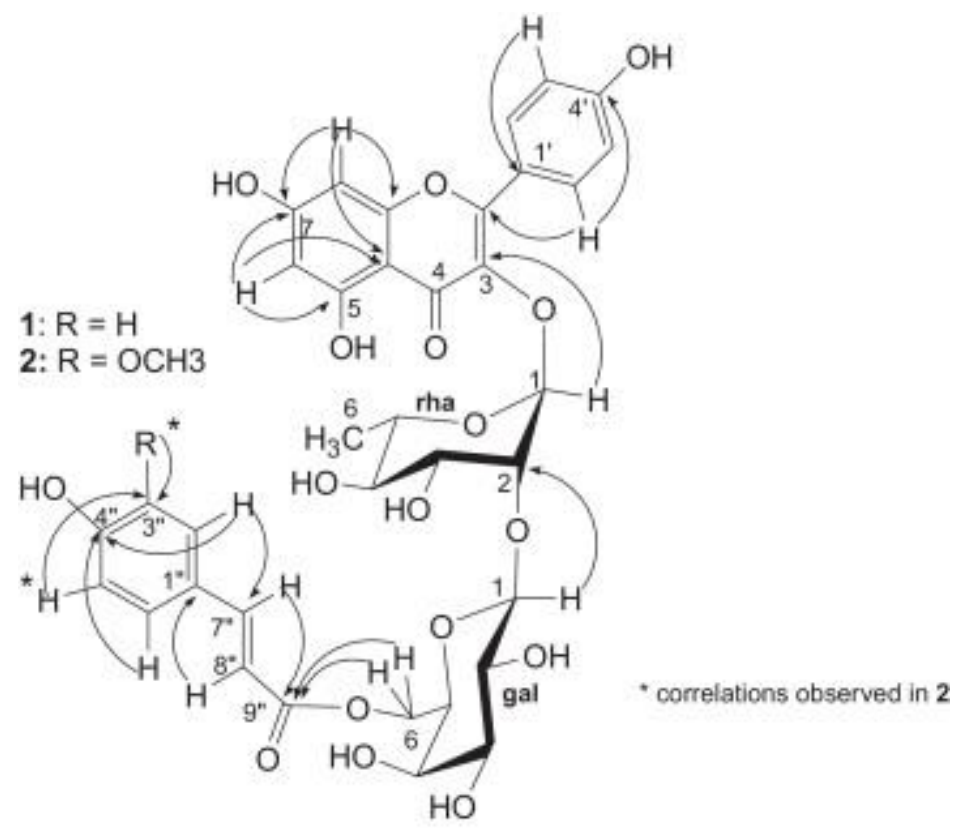

Fig. 2. Key HMBC correlations of compounds 1 and 2 from G. longipetala. 
Table 1

${ }^{1} \mathrm{H}$ and ${ }^{13} \mathrm{C}$ NMR spectroscopic data for compounds $\mathbf{1}$ and $\mathbf{2}$ (in $\mathrm{CD}_{3} \mathrm{OD}$ ).

\begin{tabular}{|c|c|c|c|c|}
\hline & 1 & & 2 & \\
\hline Aglycone & $\delta_{\mathrm{H}}(m, J$ en $\mathrm{Hz})$ & $\delta_{\mathrm{C}}$ & $\delta_{\mathrm{H}}(m, J$ en $\mathrm{Hz})$ & $\delta_{\mathrm{C}}$ \\
\hline 2 & & 158.3 & & 158.1 \\
\hline 3 & & 136.7 & & 136.7 \\
\hline 4 & & 179.5 & & 179.6 \\
\hline 5 & & 163.1 & & 163.1 \\
\hline 6 & $6.17 \mathrm{~d}(2.2)$ & 99.8 & $6.17 \mathrm{~d}(2.0)$ & 99.7 \\
\hline 7 & & 165.6 & & 165.5 \\
\hline 8 & $6.18 \mathrm{~d}(2.2)$ & 94.9 & $6.13 \mathrm{~d}(2.0)$ & 94.8 \\
\hline 9 & & 158.3 & & 158.2 \\
\hline 10 & & 106.0 & & 106.0 \\
\hline $\mathbf{1}^{\prime}$ & & 122.6 & & 122.6 \\
\hline $2^{\prime}$ & $7.70 \mathrm{~d}(8.4)$ & 131.9 & $7.69 \mathrm{~d}(8.8)$ & 131.9 \\
\hline $3^{\prime}$ & $6.93 \mathrm{~d}(8.4)$ & 116.4 & $6.94 \mathrm{~d}(8.8)$ & 116.4 \\
\hline $4^{\prime}$ & & 161.4 & & 161.5 \\
\hline $5^{\prime}$ & $6.93 \mathrm{~d}(8.4)$ & 116.4 & $6.94 \mathrm{~d}(8.8)$ & 116.4 \\
\hline $6^{\prime}$ & $7.70 \mathrm{~d}(8.4)$ & 131.9 & $7.69 \mathrm{~d}(8.8)$ & 131.9 \\
\hline \multicolumn{5}{|l|}{ 3-O-rha } \\
\hline 1 & $5.85 \mathrm{~d}(1.2)$ & 102.3 & $5.88 \mathrm{~d}(1.2)$ & 102.3 \\
\hline 2 & $4.41 \mathrm{dd}(3.5-1.2)$ & 83.6 & $4.41 \mathrm{dd}(3.6-1.2)$ & 83.7 \\
\hline 3 & 3.85 dd $(9.3-3.5)$ & 71.8 & $3.85 \mathrm{dd}(9.7-3.6)$ & 71.8 \\
\hline 4 & $3.40 \mathrm{t}(9.3)$ & 73.5 & $3.41 \mathrm{t}(9.7)$ & 73.5 \\
\hline 5 & $3,57 \mathrm{~m}$ & 72.0 & $3.61 \mathrm{~m}$ & 72.0 \\
\hline 6 & $1.07 \mathrm{~d}(6.2)$ & 17.8 & $1.11 \mathrm{~d}(6.2)$ & 17.9 \\
\hline \multicolumn{5}{|l|}{ 2rha- $O$-gal } \\
\hline 1 & $4.44 \mathrm{~d}(7.7)$ & 107.6 & $4.43 \mathrm{~d}(7.8)$ & 107.5 \\
\hline 2 & $3.64 \mathrm{dd}(9.5-7.7)$ & 72.5 & 3.64 dd (9.7-7.8) & 72.5 \\
\hline 3 & $3.57 \mathrm{dd}(9.5-3.3)$ & 74.6 & $3.57 \mathrm{dd}(9.7-3.2)$ & 74.6 \\
\hline 4 & $3.86 \mathrm{~d}(3.3)$ & 70.1 & $3.86 \mathrm{~d}(3.2)$ & 70.2 \\
\hline 5 & $3.75 \mathrm{~m}$ & 74.2 & $3.74 \mathrm{~m}$ & 74.3 \\
\hline \multirow[t]{3}{*}{6} & $4.24 \mathrm{dd}(11.4-8.0)$ & 64.0 & $4.23 \mathrm{dd}(11.4-8.3)$ & 64.1 \\
\hline & $4.40 \mathrm{dd}(11.4-4.0)$ & & $4.47 \mathrm{dd}(11.4-4.5)$ & \\
\hline & 6gal-Coum & & $6_{\mathrm{gal}}-O$-Fer & \\
\hline $1 "$ & & 126.9 & & 127.4 \\
\hline $2 "$ & $7.23 \mathrm{~d}(8.3)$ & 131.0 & $6.88 \mathrm{~d}(1.6)$ & 111.2 \\
\hline $3 "$ & $6.70 \mathrm{~d}(8.3)$ & 116.6 & & 149.1 \\
\hline $4 "$ & & 161.1 & & 150.5 \\
\hline $5 "$ & $6.70 \mathrm{~d}(8.3)$ & 116.6 & $6.69 \mathrm{~d}(8.2)$ & 116.2 \\
\hline $6 "$ & $7.23 \mathrm{~d}(8.3)$ & 131.0 & $6.83 \mathrm{dd}(8.2-1.6)$ & 124.0 \\
\hline $7 "$ & $7.47 \mathrm{~d}(16.0)$ & 146.7 & $7.44 \mathrm{~d}(15.9)$ & 146.6 \\
\hline $8 "$ & $6.04 \mathrm{~d}(16.0)$ & 114.6 & $6.06 \mathrm{~d}(15.9)$ & 115.0 \\
\hline 9”' & & 168.8 & & 168.7 \\
\hline $\mathrm{O}-\mathrm{CH}_{3}$ & & & $3.78 \mathrm{~s}$ & 56.2 \\
\hline
\end{tabular}


Table 2

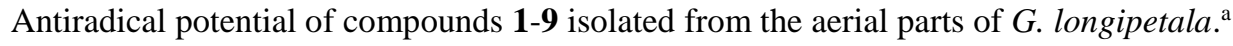

\begin{tabular}{lc}
\hline Compounds & $\begin{array}{c}\text { DPPH radical scavenging activity } \\
\mathrm{EC}_{50} \pm \text { S.D. }(\mu \mathrm{M})^{\mathrm{b}}\end{array}$ \\
\hline $\mathbf{1}$ & $\mathrm{-}^{\mathrm{b}}$ \\
$\mathbf{2}$ & $47.4 \pm 1.3$ \\
$\mathbf{3}$ & $40.4 \pm 1.5$ \\
$\mathbf{4}$ & $-\mathrm{b}$ \\
$\mathbf{5}$ & $\mathrm{-b}^{\mathrm{b}}$ \\
$\mathbf{6}$ & $\mathrm{-}^{\mathrm{b}}$ \\
$\mathbf{7}$ & $90.4 \pm 2.5$ \\
$\mathbf{8}$ & $13.8 \pm 0.2$ \\
$\mathbf{9}$ & $41.5 \pm 0.4$ \\
Ascorbic acid & $60 \pm 5.1$ \\
\hline
\end{tabular}

${ }^{a}$ Values are presented as the mean \pm S.D. $(n=3)$.

b $50 \%$ inhibition not achieved at the concentration of $100 \mu \mathrm{g} / \mathrm{ml}$.

${ }^{\mathrm{c}}$ Used as a positive control. 